\title{
Subsurface structures derived from receiver function analysis and relation to hypocenter distributions in the region from the eastern Shikoku to the northern Chugoku districts, Southwest Japan
}

\author{
Tomotake Ueno ${ }^{1,2}$, Takuo Shibutani ${ }^{1}$, and Kiyoshi Ito ${ }^{1}$ \\ ${ }^{1}$ Disaster Prevention Research Institute, Kyoto University, Uji, Kyoto 611-0011, Japan \\ ${ }^{2}$ National Research Institute for Earth Science and Disaster Prevention, Japan
}

(Received October 7, 2006; Revised December 9, 2007; Accepted February 8, 2008; Online published July 4, 2008)

\begin{abstract}
We carried out receiver function imaging to estimate detailed configurations of the Philippine Sea (PHS) slab beneath the Shikoku and Chugoku districts and crustal structures in the region. We used two temporary seismic arrays with an average station spacing of about $10 \mathrm{~km}$ in the Chugoku district. Beneath Shikoku a clear northward dipping discontinuity at about $20-40 \mathrm{~km}$ depth was found, with other discontinuities below. We present a new interpretation that the clear boundary corresponds to the under surface of a low velocity layer in the upper part of the PHS slab. We also found a discontinuity at about $60 \mathrm{~km}$ depth beneath the Chugoku district, which is thought to be the aseismic PHS slab. Small scale discontinuities were found in the crust beneath the source area of the 2000 western Tottori Earthquake and around the Median Tectonic Line. The discontinuities might relate to the occurrence of large inland earthquakes.
\end{abstract}

Key words: Receiver function, Philippine Sea plate, hypocenter distribution.

\section{Introduction}

Detailed distributions of earthquakes have recently been obtained from dense seismic networks operated by universities, national institutes and the Japan Meteorological Agency (JMA) in Japan. Miyoshi and Ishibashi (2004) obtained contour maps of the top of the Philippine Sea (PHS) slab from hypocenter distributions in southwest Japan. As a result, the seismic PHS slab was well-defined beneath the Setouchi Inland Sea. Also, Nakanishi (1980) suggested there was an aseismic PHS slab in western Chugoku by analyzing $S c S p$ phases.

Yamauchi et al. (2003) and Shiomi et al. (2004) obtained depth contour maps of the PHS slab in southwest Japan by receiver function analyses for the recent seismic network data. They interpreted the PHS slab image as the oceanic Moho discontinuity of the PHS plate. In this interpretation, earthquakes are thought to occur in the upper mantle of the subducting PHS plate beneath eastern Shikoku. Similarly, Kurashimo et al. (2002) reported that the earthquakes existed in the mantle beneath there from results of refraction and wide-angle reflection surveys.

On the other hand, Ohkura (2000) concluded the earthquakes occurred in the oceanic crust of the PHS plate and/or the plate boundary, since guided phases were recorded at stations in the Chugoku district from earthquakes occurring beneath Shikoku. Shibutani (2001) obtained an $S$ wave velocity structure by analyzing receiver functions and wide-angle reflection phases below eastern Shikoku, and

Copyright (c) The Society of Geomagnetism and Earth, Planetary and Space Sciences (SGEPSS); The Seismological Society of Japan; The Volcanological Society of Japan; The Geodetic Society of Japan; The Japanese Society for Planetary Sciences; TERRAPUB suggested that the subcrustal earthquakes occurred in the oceanic crust and/or at the plate boundary.

A large earthquake $\left(M_{\mathrm{w}} 6.6\right)$ occurred on 6 October 2000 , in western Tottori Prefecture in southwest Japan (Shibutani et al., 2002, 2005). Nishida et al. (2002) carried out seismic explosion surveys in the aftershock area of this earthquake, and obtained reflectors at the depths of about 12, 30 and $60 \mathrm{~km}$. In eastern Shikoku, there exists the Median Tectonic Line (MTL) which is the most significant fault in southwest Japan. Ito et al. (1996) found a sharp reflector dipping 30$40^{\circ}$ north in the upper crust by a seismic reflection survey. Kawamura et al. (2003) and Sato et al. (2005) also found that the sharp reflector extended to the lower crust from a recent seismic explosion survey. Although the subsurface structures in these regions have become clearer by analyzing geophysical data, the relations among the structures or between the structures and hypocenter distributions are not still clear.

In this study, we estimated the subsurface structures from the crust to the upper mantle, and compared them to hypocenter distributions. To investigate the subsurface structures, we used dense seismic networks deployed from the northern Chugoku and eastern Shikoku districts, including the source area of the 2000 western Tottori Earthquake (Fig. 1), and analyzed receiver functions calculated by a multiple-taper method (Park and Levin, 2000). The purposes of this study are (1) to investigate relationships between the locations of hypocenters and the configuration of the PHS slab in the eastern Shikoku region, (2) to image the Moho discontinuity and the discontinuity at $60 \mathrm{~km}$ depth beneath the northern Chugoku district, and to discuss the relationships between the discontinuity at the $60 \mathrm{~km}$ 


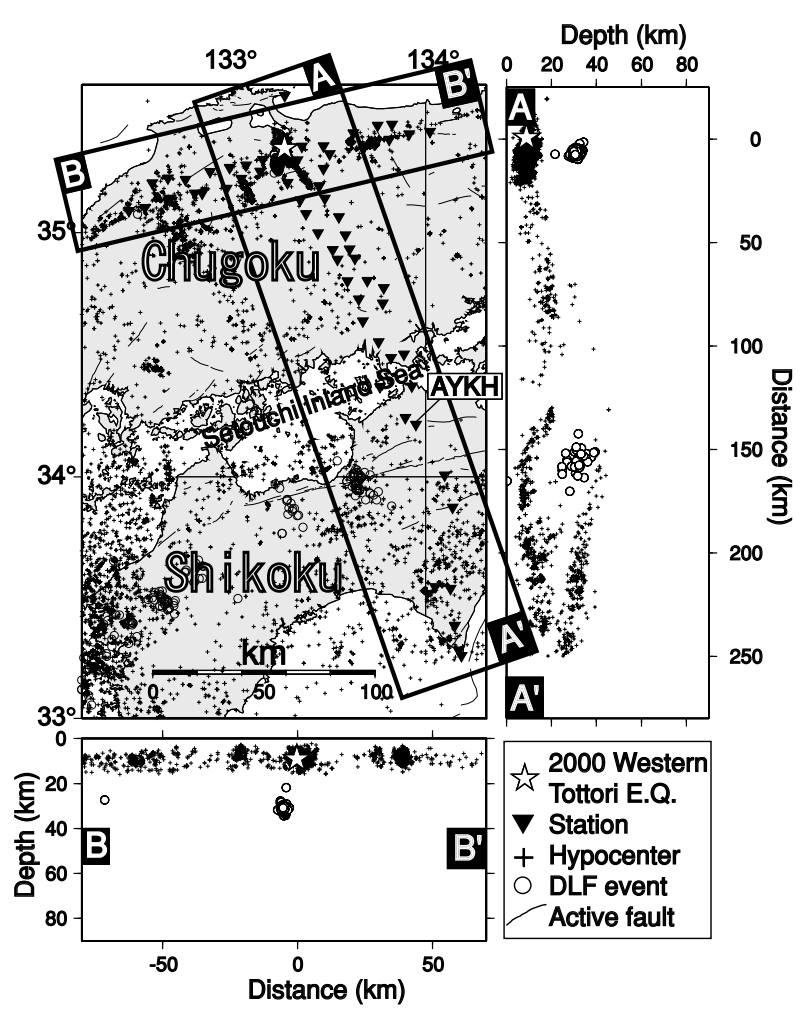

Fig. 1. Distributions of seismic stations (inverted triangles) used in this study and hypocenters in southwest Japan determined by JMA. Plus signs show hypocenters $(M>0.5)$ from 2002-2004. Open circles indicate DLF earthquakes. Thin solid lines show active faults. The earthquakes and DLF earthquakes in the boxes $\mathrm{A}-\mathrm{A}^{\prime}$ and $\mathrm{B}-\mathrm{B}^{\prime}$ are plotted in the depth sections of $\mathrm{A}-\mathrm{A}^{\prime}$ and $\mathrm{B}-\mathrm{B}^{\prime}$, respectively.

depth and the aseismic PHS slab, and (3) to find relationships between discontinuities and hypocenter distributions in the crust in the source area of the 2000 western Tottori Earthquake and around the MTL.

\section{Method}

\subsection{Data}

We used waveform data recorded at 63 seismic stations in a cross-shaped array ( $\mathrm{A}-\mathrm{A}^{\prime}$ and $\mathrm{B}-\mathrm{B}^{\prime}$ lines in Fig. 1) from 2002 to 2004 . The arrays included 28 permanent stations of the National Research Institute for Earth Science and Disaster Prevention (NIED), JMA, Kochi University and Kyoto University. The two lines of stations intersected in the source region of the 2000 western Tottori Earthquake. The average station spacing of the arrays was about $10 \mathrm{~km}$ in the Chugoku district. These temporary stations were operated by the Japanese University Group of the Joint Seismic Observation in the Southwestern Japan (2002). Most stations were equipped with three-component short-period seismometers with a natural period of $1 \mathrm{~s}$. The earthquake parameters used in this study are provided by the U.S. Geological Survey (USGS). 70 earthquakes with epicentral distances between 30 and $80^{\circ}$ and closer events with the depths greater than $300 \mathrm{~km}$ were chosen, as shown in Fig. 2. Figure 3 shows an example of the $P$ waveforms of the vertical and radial components recorded along the $\mathrm{A}-\mathrm{A}^{\prime}$ line. The waveforms have good correlations among the stations and also between the components. Phases within several sec-

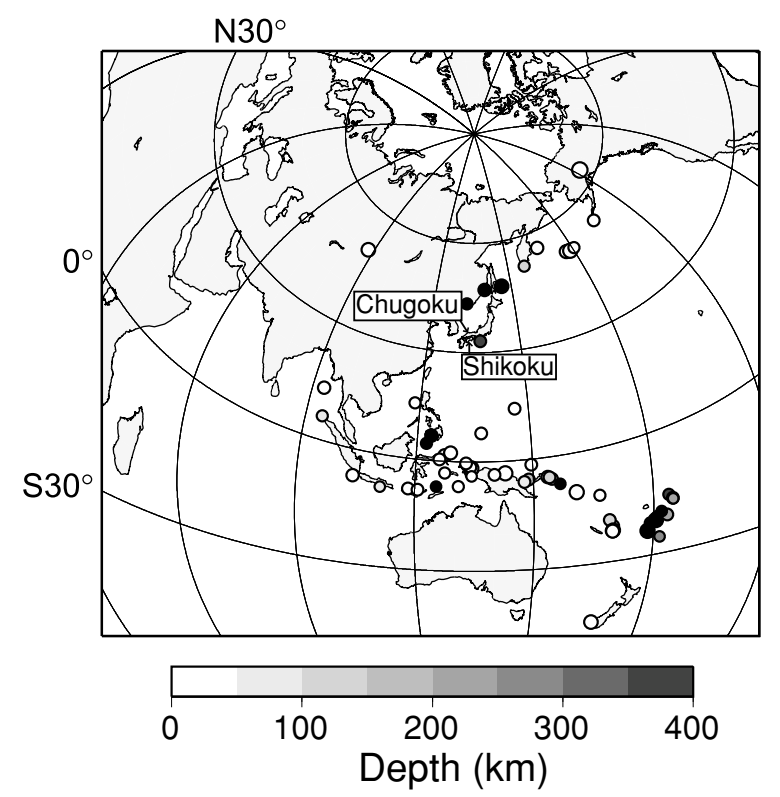

Fig. 2. Epicenter distribution of teleseismic events used in this study. Gray scale shows depths of the events.
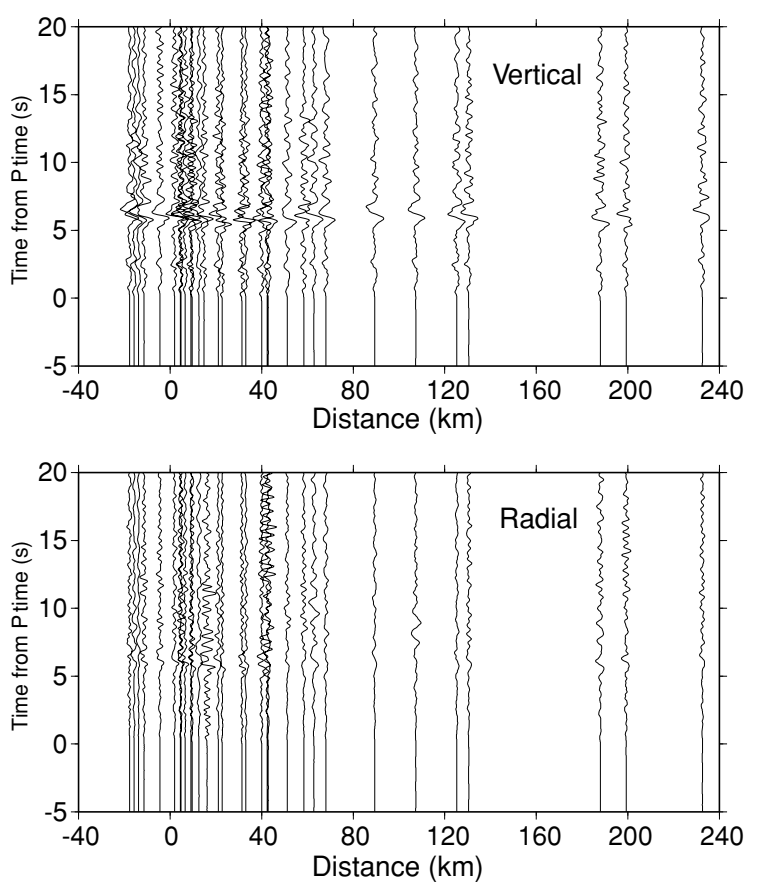

Fig. 3. Record sections of the vertical (upper figure) and the radial (lower figure) components of an earthquake recorded along the $\mathrm{A}-\mathrm{A}^{\prime}$ line in Fig. 1. The earthquake $\left(M_{\mathrm{w}} 6.4\right)$ occurred in the Malay Archipelago on October 18, 2003. The origin of the $x$-axis is the epicenter of the 2000 western Tottori Earthquake.

onds after the $P$ onset may be caused by source processes. We try to remove the source effects and emphasize phases caused by velocity discontinuities beneath each station by the receiver function analysis.

\subsection{Analyses}

2.2.1 Receiver function estimation The $P$-wave and its coda from teleseismic events contain information of the earthquake source and local structure, especially phases converted from $P$ to $P(P p)$ and $P$ to $S(P s)$ at local dis- 


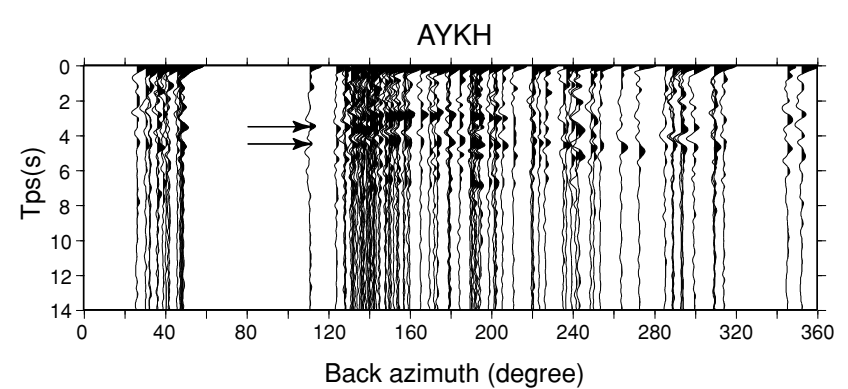

Fig. 4. Example of radial receiver functions ordered by back azimuths at station AYKH. Arrows show the phases of the $P s$ converted waves.

continuities, and reverberations. Because the effect of the earthquake source and $P$-wave reverberations are removed, $S$-waves arriving at the surface are enhanced in receiver functions (e.g., Langston, 1979; Owens et al., 1984; Ammon, 1991). We assume that individual $P s$ phases correspond to structure boundaries. Receiver functions are calculated by a deconvolution of the radial component by the vertical component which contains mainly $P$-waves. The simplest way to accomplish this calculation is to divide the frequency spectrum of the radial component by the spectrum of the vertical component. In order to stably calculate this division in the frequency domain, a water level (a minimum allowable amplitude) is often applied to the power spectrum of the vertical component in order to fill spectral holes in the denominator (e.g., Helmberger and Wiggins, 1971). The spectral holes occur as a result of using a taper with a limited time length or a waveform with a low signalto-noise ratio (Soda et al., 2001). Smaller water levels can not sufficiently fill the spectral holes, while larger water levels tend to contaminate the spectral amplitudes. Therefore, we have to choose carefully water levels according to the power spectrum of the individual vertical component.

Since we calculated many receiver functions in this study, the water level method was unsuitable. To circumvent this problem, we applied the multiple-taper method (Park and Levin, 2000) for the calculation of receiver functions. We fixed parameters of the multiple-taper method to be $P=4$ and $K=3$, where $P$ is the time-bandwidth product and $K$ is the number of the eigentapers. The taper length $T$ was $60 \mathrm{~s}$. Since the half width of spectral leakage $W$ is calculated by $P / T$ (Park et al., 1987), $W$ becomes about $0.07 \mathrm{~Hz}$. The time domain receiver functions obtained with these parameters tended to have low amplitudes for delay times greater than $8 \mathrm{~s}$. We excluded high frequency noise by a Gaussian low-pass filter with a corner frequency of about 1-2 Hz (e.g., Owens et al., 1984). Figure 4 shows a record section of receiver functions ordered by back azimuths at station $\mathrm{AYKH}$ on the $\mathrm{A}-\mathrm{A}^{\prime}$ line, processed by the multiple-taper deconvolution. In order to enhance coherent phases of the receiver functions, a singular value decomposition (SVD) filter was applied to the waves in the time domain. The SVD filtering with the largest six eigenvalues provided a better receiver function image (Chevrot and Girardin, 2000).

2.2.2 Imaging Since the phases of receiver functions correspond to boundaries of the $S$-wave velocity structure, the time axis of the receiver functions can be transformed into the depth axis using a 1-D velocity structure, such as JMA2001 (Ueno et al., 2002). Assuming that a plane $P$ wave impinging on an interface from below, the delay time, $T_{p s}$, of the converted $P s$ phase from the direct $P p$ phase, is given by the following equation,

$$
T_{p s}(Z)=\int_{0}^{Z}\left(\sqrt{\frac{1}{\beta(z)^{2}}-p^{2}}-\sqrt{\frac{1}{\alpha(z)^{2}}-p^{2}}\right) d z
$$

where $\alpha$ and $\beta$ are $P$ and $S$-wave velocities as a function of depth $z$, respectively. $Z$ denotes the depth of the interfaces. $p$ is the ray parameter. The depth series of each receiver function can be represented by a bending ray with the ray parameter and a backazimuth. We projected the rays onto $1 \mathrm{~km}$ by $1 \mathrm{~km}$ cells for the two array profiles. When two or more rays were projected onto the same cell, the amplitudes were averaged. Figures 5-8 show the images of $P s$ converters obtained by this method. In the figures, the positive (negative) amplitudes of the receiver functions are shown with red (blue) colors and indicate velocity discontinuities from fast (slow) to slow (fast) for upward rays.

\section{Results}

\subsection{Estimates of receiver functions}

The receiver functions calculated with the multiple-taper method were more stable than those with the water level method. Strong positive pulses at 3 and $4.5 \mathrm{~s}$ are observed in the radial receiver functions shown in Fig. 4, and they indicate interfaces in the crust and the upper mantle beneath station AYKH. The pulses appear from back azimuths of 110 to $250^{\circ}$. This result indicates that the receiver functions are affected by different structures for different arrival directions of the incident $P$-waves. We identified these pulses as velocity discontinuities (i.e., the Moho discontinuity and/or the plate boundary of the PHS plate). The images obtained in this study show clearer results in Chugoku, the Seto Inland Sea and northern Shikoku, than previous receiver function studies (e.g., Yamauchi et al., 2003; Shiomi et al., 2004) because of a higher density of seismic observation stations. From the result of these two profiles, we obtained the velocity discontinuity structures.

\section{$3.2 \quad \mathrm{~A}-\mathrm{A}^{\prime}$ line}

Figure 5(a) shows the receiver function image of the $P s$ converted waves beneath the $\mathrm{A}-\mathrm{A}^{\prime}$ line in Fig. 1. Continuous red cells (R1) are located clearly at 20-40 km depth beneath the Shikoku and the southern Chugoku districts. The R1 surface with a dip of about $10^{\circ}$ becomes gradually deeper towards the north. In the northern Chugoku district, there are continuous red cells (R2) at $30 \mathrm{~km}$ depth and deepen to about $40 \mathrm{~km}$ towards the south in the middle of the Chugoku district. Moreover, there are continuous yellow cells $\left(\mathrm{R} 1^{\prime}\right)$ dipping towards the north at about $60 \mathrm{~km}$ depth beneath the northern Chugoku district. In addition, there are small scale discontinuities at depths of 12-20 km in the crust, especially beneath the aftershock area of the 2000 western Tottori Earthquake and around the deeper portion of the MTL. 


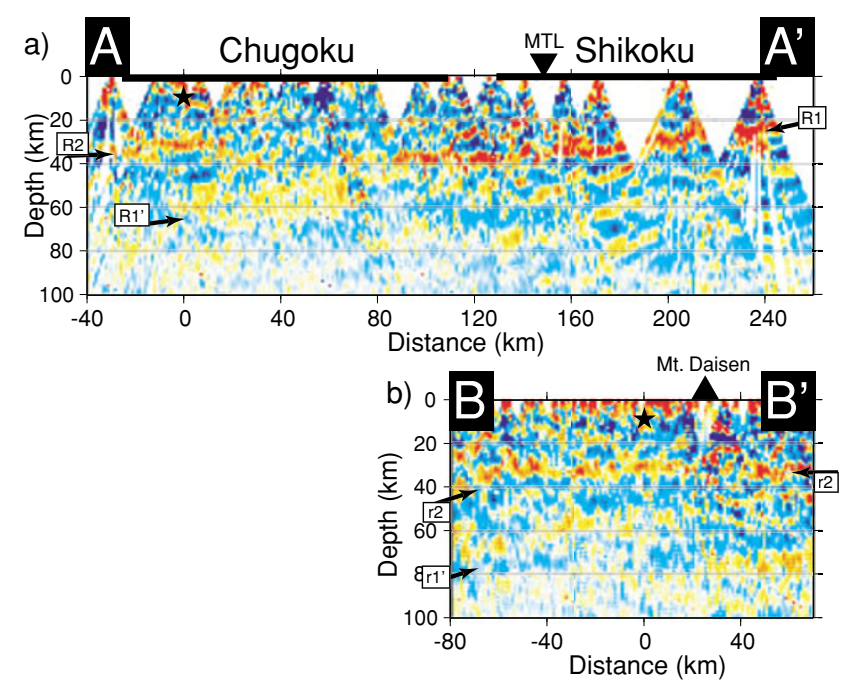

Fig. 5. Cross sections of receiver function images. (a) and (b) show the images along the $\mathrm{A}-\mathrm{A}^{\prime}$ and $\mathrm{B}-\mathrm{B}^{\prime}$ lines shown in Fig. 1, respectively. Red and blue colors indicate the positive and negative amplitudes of the receiver functions, respectively. A star shows the hypocenter of the 2000 western Tottori Earthquake, which indicates the origin of the $x$-axis.
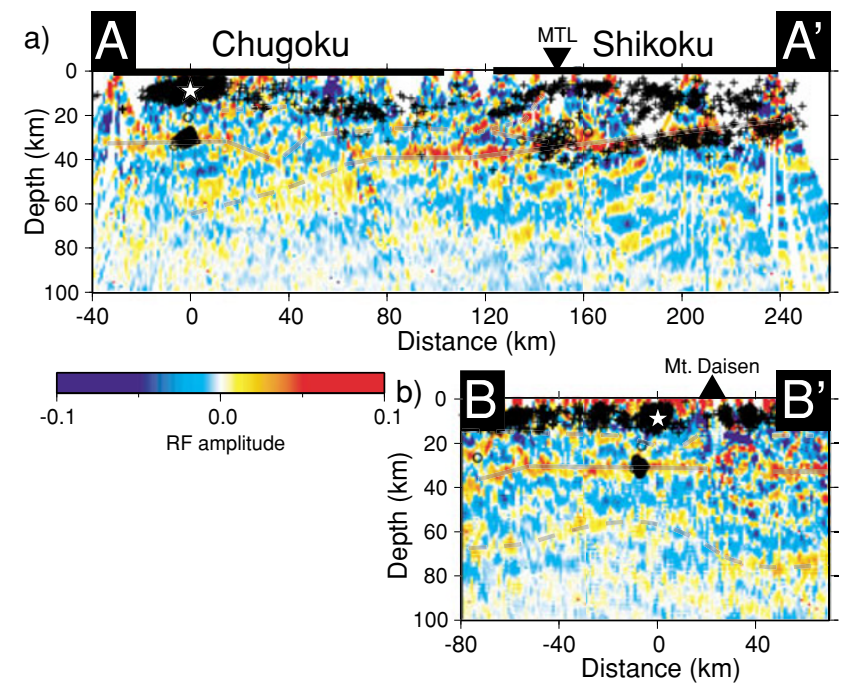

Fig. 6. Cross sections of the receiver function images with seismic activity. Solid lines indicate clear discontinuities, the plate boundary and the Moho discontinuity. Dashed lines indicate other discontinuities in the crust and upper mantle. Plus signs and open circles indicate earthquakes and DLF earthquakes, respectively. A star shows the hypocenter of the 2000 western Tottori Earthquake, which indicates the origin of the $x$-axis.

\subsection{B-B' line}

Figure 5(b) shows the receiver function image of the $P s$ converted waves beneath the B-B' line in Fig. 1. At the depth of $30 \mathrm{~km}$, there are continuous horizontal red cells (r2). This discontinuity is disturbed beneath Mt. Daisen. It is possible that this is an artifact as discussed in the next section. Continuous yellow cells $\left(\mathrm{r}^{\prime}\right)$ are found at approximately 60 to $70 \mathrm{~km}$ depth, which correspond to R1' in Fig. 5(a).

\section{Discussion}

We obtained the 2-D images of the receiver functions (Figs. 5-7) on an assumption that the structure does not
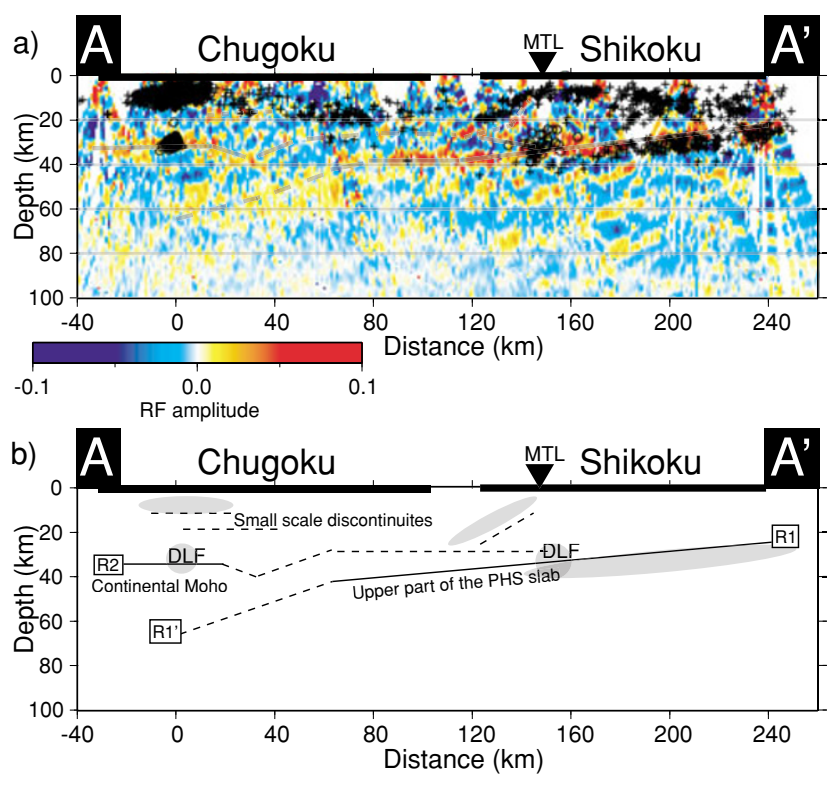

Fig. 7. Schematic models for the $\mathrm{A}-\mathrm{A}^{\prime}$ section in Fig. 1. (a) shows the cross section of the receiver function image for the $\mathrm{A}-\mathrm{A}^{\prime}$ section with seismic activity. In model (b) the clear red cells are assumed to be the upper part of the PHS slab. Shaded areas show active seismicity.

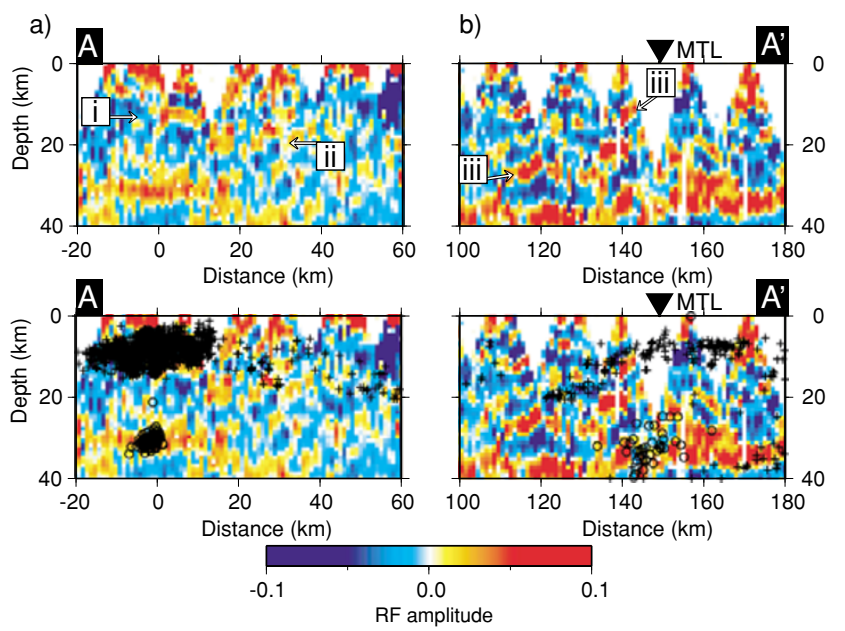

Fig. 8. Enlarged shallow portions of the cross section of the receiver function image in Figs. 5(a) and 6(a) around the 2000 western Tottori Earthquake (a) and the MTL (b). i, ii, iii show small scale discontinuities. In the lower two figures, seismicity near the cross sections is superimposed on the same images as in the upper figures.

change very much along the short side of the boxes. The assumption of the 2-D structure in the box $A-\mathrm{A}^{\prime}$ is considered valid because isodepth contours related to the subducting PHS plate derived from the earthquake distribution (e.g., Miyoshi and Ishibashi, 2004) and other receiver function studies (e.g., Yamauchi et al., 2003; Ueno et al., 2008) and geotectonics in southwest Japan are roughly perpendicular to the $\mathrm{A}-\mathrm{A}^{\prime}$ profile line and do not show abrupt changes in the studied area. It is not well known that the structure changes along the short side of the box B-B'. However, the receiver function image along the profile $B-B^{\prime}$ is less subject to the structural change in the short direction because most of the receiver functions sample only the southern area of the box. 
We discuss in detail the relationship between the discontinuities derived from the receiver function analysis and the hypocenter distributions in the following three sections.

\subsection{Relation of slab to subcrustal earthquakes in east- ern Shikoku}

Our receiver function images and hypocenter distribution shown in Fig. 7(a) show that the hypocenters beneath Shikoku are located beneath the continuous red cells (R1), indicating that most of the earthquakes are below the discontinuity. The depth of R1 is similar to one derived from previous receiver function studies. Yamauchi et al. (2003) and Shiomi et al. (2004) suggested that the continuous red cells (R1) from southern Shikoku to central Chugoku correspond to the oceanic Moho discontinuity in the PHS plate. If their suggestion is correct, the subcrustal earthquakes beneath eastern Shikoku occur below the oceanic Moho discontinuity and deep low frequency (DLF) earthquakes occur around the oceanic Moho discontinuity.

Kurashimo et al. (2002) constructed a $P$-wave velocity model from refraction and wide-angle reflection data and pointed out that the oceanic Moho discontinuity was shallower than the subcrustal earthquakes. However, the phases of reflections from the oceanic Moho discontinuity in their study were obscure. Although the clear R1 cells in this study locate at similar depths to the oceanic Moho discontinuity, it seems improbable that they correspond to the obscure reflectors of Kurashimo et al. (2002).

Kodaira et al. (2002) pointed out the existence of water at the PHS plate boundary by analyzing reflected phases with large amplitudes recorded in an onshore-offshore deep seismic survey conducted in the western Nankai Trough seismogenic zone, and estimated the very thin layer (about $300 \mathrm{~m}$ ) with very low velocity at the plate boundary. Kurashimo et al. (2002) also suggested a very low velocity layer with $1 \mathrm{~km}$ thickness at the upper most part of the PHS slab obtained from the same waveform calculation for very clear reflected phases as Kodaira et al. (2002). Although there are slight differences between their low velocity models (i.e., the location and the thickness of the low velocity layer), they both suggested the existence of the low velocity layers around the plate boundary. The $\mathrm{R} 1$ discontinuity possibly indicates the lower boundary of the low velocity layer, though there is a question that receiver functions can detect such thin layers. Ueno et al. (2008) calculated synthetic receiver functions for a thin low velocity layer, and showed that the receiver function was sensitive to a thin layer with at least $1 \mathrm{~km}$ thickness when a large velocity gap existed.

Recently, Sato et al. (2005) determined that the thickness of the reflective layer around the PHS plate boundary was about $7 \mathrm{~km}$ from a seismic reflection survey across the overall Outer Zone of Southwest Japan from eastern Shikoku to eastern Chugoku. They interpreted the reflective layer as a contamination zone of the oceanic layers 1 and 2 and the base of the continental plate. The R1 discontinuity is located at the similar depth of the base of the reflective layer.

In addition, Yamaguchi et al. (1999) gave a similar result by a network MT investigation in eastern Shikoku and suggested that the thin high-conductive layer (about $10 \mathrm{~km}$ ) is caused by pore water and/or sediments in the upper part of the subducting PHS plate. Katsumata and Kamaya (2003) suggested that the most plausible liquid causing tremor is water because a large quantity of water is transported by the subduction of the PHS plate. Nugraha and Mori (2006) found that the DLF earthquakes occur at high $V_{p} / V_{s}$ area and suggested that the occurrence of the DLF earthquakes were involved with fluids. The layer with a large amount of water indicates very low velocity and the DLF earthquakes occur in it. As shown in Fig. 6(a), the DLF earthquakes occur around the R1. Therefore, the R1 can be the lower boundary of the low velocity layer.

To summarize this section, the reflective low velocity layer obtained from the seismic surveys and the highconductive layer from the MT investigation are considered to be commonly caused by the existence of water supplied in the subducting processes beneath the onshore-offshore region in eastern Shikoku. As the result, a large velocity contrast exists at the base of the reflective low velocity layer and the $\mathrm{R} 1$ in our receiver function image can correspond to the discontinuity as shown in Fig. 7(b). Consequently most earthquakes associated with the subducting PHS plate occur at the plate boundary and/or the oceanic crust beneath eastern Shikoku as well as in other regions, such as western Shikoku and the eastern Kii Peninsula. Ohkura (2000) found later phases in seismograms at observation stations in the Chugoku and Kinki districts for earthquakes beneath Shikoku, and interpreted the later phases as guided waves in the low velocity layer in the oceanic crust. The conclusion that the earthquakes occurred within the low velocity layer is consistent with our interpretation.

\subsection{Upper mantle discontinuities beneath Chugoku}

In the northern Chugoku district, the Moho discontinuity appeared clearly at $30 \mathrm{~km}$ depth (R2 in Fig. 5(a)). This discontinuity reaches about $40 \mathrm{~km}$ in the central Chugoku district. This dipping Moho beneath the Chugoku district is consistent with low Bouguer gravity anomalies in the region (Gravity Research Group in Southwest Japan, 2001). In the B-B' line (Fig. 5(b)) the Moho discontinuity (r2) is also located at about $30 \mathrm{~km}$ depth. $\mathrm{r} 2$ becomes obscure beneath Mt. Daisen at about $20 \mathrm{~km}$ along the horizontal axis. It is possible that this is an artifact because seismic stations located in this area did not have good recordings due to thick pyroclastic material from Daisen volcano.

DLF earthquakes occur around the Moho discontinuity beneath the aftershock area of the 2000 western Tottori Earthquake as shwon in Fig. 7(a). Most DLF events are not tremor, but earthquakes which have predominant frequencies of $2-4 \mathrm{~Hz}$, and $P$-waves with a high-frequency component in the onset (Ohmi and Obara, 2002). Ohmi and Obara (2002) indicated that the mechanism of DLF earthquakes were single-forces which suggested transport of fluids, such as water or magma. These fluid materials might affect the $S$-wave velocity. However, we could not obtain any characteristic receiver function images at the Moho discontinuity around the hypocenters of DLF earthquakes. The volume of these fluids might not be large enough to be detected by the receiver function analysis.

In Fig. 5, a discontinuity ( $\mathrm{R} 1^{\prime}$ or $\left.\mathrm{r}^{\prime}{ }^{\prime}\right)$ is seen at $50-60 \mathrm{~km}$ depth beneath the source area of the 2000 western Tottori Earthquake. This discontinuity was recognized also by a reflection survey (e.g., Nishida et al., 2002; Doi et al., 
2003), and inclines to the north (Fig. 5(a)). Although the $\mathrm{r}^{\prime}$ ' image is week, it is deeper beneath east area than west (Fig. 5(b)). As shown in Fig. 6, this discontinuity seems to be an extension of the upper part of the PHS slab (R1'). The discontinuity is not as clear as R1 in Fig. 5(a). A possible reason for the diffuse observation is a characteristic of the multiple-taper method which tapers the amplitudes of the receiver functions for delay times greater than $8 \mathrm{~s}$, that is, for the depths greater than $60 \mathrm{~km}$.

\subsection{Hypocenter distributions and discontinuities in the crust}

We found small scale discontinuities in the crust in this study. A shallow portion of our results is enlarged in Fig. 8. In the Chugoku district beneath the area of the 2000 western Tottori Earthquake, there are two discontinuities at about 12 and $20 \mathrm{~km}$ depth ('i' and 'ii' in Fig. 8). The discontinuity 'i' exists beneath the source area of the 2000 western Tottori Earthquake and may correspond to a reflector observed by Nishida et al. (2002), and to the top of a zone of large scattering coefficient (Matsumoto et al., 2002; Asano and Hasegawa, 2004). Another discontinuity 'ii' exists beneath the southern region of the source area. This discontinuity does not coincide with any large scattering coefficient zone although the spatial resolution of their studies may not be adequate to be compared with our result in this region. As shown in Fig. 8(a), comparing 'i' and 'ii' with the hypocenter distribution, we found the shallower discontinuity ' $i$ ' is located at the base of the seismogenic zone and the deeper discontinuity 'ii' is located several kilometers below. There might be a distinctive relationship among the discontinuities, the areas of large inland earthquakes and active faults. Ueno et al. (2005) suggested a relationship between velocity discontinuities and seismogenic zones in the crust beneath the Atotsugawa Fault which is an active fault located in central Japan. The fault is approximately $60 \mathrm{~km}$ long with right-lateral displacement. They identified discontinuities from reflection and refraction surveys, and presented a four layer model composed of a surface, upper crust (brittle), middle (brittle-ductile transition), and lower (ductile) layers. The 'i' and 'ii' discontinuities may correspond to the boundaries between the upper and middle, and middle and lower crust, respectively. The 'i' discontinuity is seen only beneath the area of the 2000 western Tottori Earthquake, and may be a characteristic structure around a large earthquake.

Beneath the area around the MTL in Shikoku, there is a dipping discontinuity ('iii' in Fig. 8). This discontinuity is distributed under the northern portion of the surface trace of the MTL. The location of this discontinuity is similar to a reflector derived from a seismic explosion survey (Kawamura et al., 2003; Sato et al., 2005). Therefore, we can identify the boundary as the deep extension of the MTL. The distribution of hypocenters around the MTL dips northwards at an angle of $30-40^{\circ}$. The discontinuity 'iii' is located several kilometers below the dipping distribution of hypocenters. Tabei et al. (2002) presented a model with a $35-45^{\circ}$ northward dipping fault plane for the MTL, which is fully locked in the upper portion to a depth of $15 \mathrm{~km}$, and slips steadily in the right lateral motion at $5 \mathrm{~mm} / \mathrm{yr}$ below that depth. The model explained the GPS velocity field from which elastic deformation caused by the PHS subduction had been removed. The discontinuity 'iii' possibly corresponds to the aseismic fault plane of Tabei's model. The MTL is one of the most active and longest faults on land in Japan, and is a potential source of large destructive earthquakes (Goto et al., 2001). This discontinuity 'iii' might be a special structure below the area of large inland earthquakes.

Ito (1999) constructed a model explaining a relationship between the lower limit of seismogenic zones and heat flow structures. He suggested large inland earthquakes would occur in areas where the depths of seismogenic zones changed abruptly. This lateral change of the seismogenic layer thickness was correlated to the large lateral temperature gradients caused by high pressure and high temperature fluid or magma in the crust (Ito, 1999). The discontinuities ('i', 'ii', 'iii') in the crust are possibly related to the structures affected by such materials.

\section{Conclusions}

We applied a multiple-taper receiver function method to the teleseismic waveform data recorded by temporary seismic arrays and permanent stations. Since we used a high density set of seismic stations, we were able to obtain high resolution receiver function images along the arrays in the region from eastern Shikoku to northern Chugoku districts, southwest Japan. From the results, we concluded as follows,

1) In the Shikoku to southern Chugoku districts, a clear discontinuity dips slightly to the north. We infer this to be the lower surface of the low velocity layer in the upper part of the PHS slab. This interpretation implies that most subcrustal earthquake occurs at the plate boundary and/or in the oceanic crust beneath eastern Shikoku.

2) In the northern Chugoku district, we observe the Moho discontinuity at about $30 \mathrm{~km}$ depth. We also find a discontinuity at $50-60 \mathrm{~km}$ depth dipping to the northwest. This discontinuity might indicate the deep extension of the PHS slab.

3) Small scale discontinuities in the crust seem to be located at the base of the seismogenic zone and at several kilometers below in the area of the 2000 western Tottori Earthquake. These discontinuities correspond to seismic reflectors. Around the MTL, we found a north dipping boundary in the lower crust which may correspond to the fault plane of the MTL, which inferred from GPS velocity field. These discontinuities may indicate a relationship between a characteristic structure and large inland earthquakes.

Acknowledgments. We thank Kazuro Hirahara, James Mori, Yoshihisa Iio, Shiro Ohmi, Hiroshi Katao, Ryokei Yoshimura, Ken'ichi Yamazaki, and Issei Doi for their useful comments. We are also grateful to two anonymous reviewers for their valuable comments. Issei Doi and Tomohiko Ogasawara helped us in reading seismograms. We referred to the program provided by Jeffrey Park to calculate the multiple-taper receiver function. We used the temporary seismic station arrays operated by the Japanese University Group of the Joint Seismic Observation in the Southwestern 
Japan. The data recorded by the permanent seismic stations are provided by JMA, NEID, Kochi University, and Kyoto University. We used the computer system of the Kyoto University Active Geosphere Investigations for the 21st Century Centers of Excellence Program (KAGI21). We also used GMT software (Wessel and Smith, 1991) to draw the figures.

\section{References}

Ammon, C. J., The isolation of receiver effects form teleseismic $P$ waveforms, Bull. Seismol. Soc. Am., 81, 2504-2510, 1991.

Asano, Y. and A. Hasegawa, Imaging the fault zones of the 2000 western Tottori earthquake by a new inversion method to estimate threedimensional distribution of the scattering coefficient, J. Geophys. Res., 109, B06306, doi:10. 1029/2003JB002761, 2004.

Chevrot, S. and N. Girardin, On the detection and identification of converted and reflected phases from receiver functions, Geophys. J. Int., 141, 801-808, 2000.

Doi, I., K. Nishigami, K. Tadokoro, and A. Shimokawa, Three Dimensional Distribution of $S$ Wave Reflectors in and around the Source Region of the 2000 Western Tottori Earthquake, Earth Monthly, 25, 647651, 2003 (in Japanese).

Goto, H., T. Nakata, H. Tsutsumi, K. Okumura, T. Imaizumi, T. Nakamura, and T. Watanabe, The Latest Surface-Faulting Events on the Median Tectonic Line in Shikoku, Southwest Japan, Based on Mini-Trenching and Geoslicer Studies, Zisin 2 (J. Seismol. Soc. Jpn.), 53, 205-219, 2001 (in Japanese with English abstract).

Gravity Research Group in Southwest Japan, Cravity database of southwest Japan [CD-ROM], Bull. Nagoya Univ. Museum Special Report, 9, Nagoya, Japan, 2001.

Helmberger, D. V. and R. Wiggins, Upper mantle structure of midwestern Unites States, J. Geophys. Res., 76, 3229-3245, 1971

Ito, K., Seismogenic layer, reflective lower crust, surface heat flow and large inland earthquakes, Tectonophysics, 306, 423-433, 1999.

Ito, T., T. Ikawa, S. Yamakita, and T. Maeda, Gently north-dipping Median Tectonic Line (MTL) revealed by recent seismic reflection studies, southwest Japan, Tectonophysics, 264, 51-63, 1996.

Japanese University Group of the Joint Seismic Observation in the Southwestern Japan, The Joint Seismic Observations at the Southwestern Japan, Program. Abst., Seismol. Soc. Jpn., P004, 2002 (in Japanese)

Katsumata, A. and N. Kamaya, Low-frequency continuous tremor around the Moho discontinuity away from volcanoes in the southwest Japan, Geophys. Res. Lett., 30, doi: 10.1029/2002GL015981, 2003.

Kawamura, T., M. Onishi, E. Kurashimo, T. Ikawa, and T. Ito, Deep seismic reflection experimet using a dense receiver and sparse shot technique for imaging the deep structure of the Median Tectonic Line (MTL) in east Shikoku, Japan, Earth Planets Space, 55, 549-557, 2003.

Kodaira, S., E. Kurashimo, J.-O. Park, N. Takahashi, A. Nakanishi, S. Miura, T. Iwasaki, N. Hirata, K. Ito, and Y. Kaneda, Structural factors controlling the rupture process of a megathrust earthquake at the Nankai trough seismogenic zone, Geophys. J. Int., 149, 815-835, 2002.

Kurashimo, E., M. Tokunaga, N. Hirata, T. Kaneda, K. Ito, R. Nishida, and S. Kimura, Geometry of the subducting Philippine Sea plate and the crustal and upper mantle structure beneath eastern Shikoku Island revealed by seismic refraction/wide-angle reflection profiling, Zisin 2 (J. Seismol. Soc. Jpn.), 54, 489-505, 2002 (in Japanese with English abstract).

Langston, C., Structure under Mount Rainier, Washington, inferred from telesesimic body waves, J. Geophys. Res., 84, 4749-4762, 1979.

Matsumoto, S., K. Obara, N. Kimura, and M. Nakamura, Imaging $P$-wave Scatterer Distribution around the Focal Area of the 2000 Western Tottori Earthquake ( $M_{\mathrm{w}}$ 6.6), Zisin 2 (J. Seismol. Soc. Jpn.), 55, 229-232, 2002 (in Japanese).

Miyoshi, T. and K. Ishibashi, Geometry of the seismic Philippine Sea Slab beneath the region from Ise bay to Western Shikoku, Southwest Japan, Zisin 2 (J. Seismol. Soc. Jpn.), 57, 139-152, 2004 (in Japanese with English abstract).

Nakanishi, I., Precursors to $\mathrm{ScS}$ phases and dipping interface in the upper mantle beneath southwestern Japan, Tectonophysics, 69, 1-35, 1980.

Nishida, R., N. Hirata, K. Ito, Y. Umeda, T. Igawa, and M. Onishi, Subsurface survey beneath the western Tottori region (Part 1), Program. Abst., Seismol. Soc. Jpn., P62, 2002 (in Japanese).

Nugraha, D. A. and J. Mori, Three-dimensional Velocity Structure in the Bungo Channel and Shikoku Area, Japan, and its Relationship to Low-frequency Earthquakes, Geophys. Res. Lett., 33, L24307, doi:10. 1029/2006GL028479, 2006.
Ohkura, T., Structure of the upper part of the Philippine Sea plate estimated by later phases of upper mantle earthquakes in and around Shikoku, Japan, Tectonophysics, 321, 17-36, 2000.

Ohmi, S. and K. Obara, Deep low-frequency earthquakes beneath the focal region of the $M_{\mathrm{w}} 6.72000$ Western Tottori earthquake, Geophys. Res. Lett., 29, doi:10.1029/2001GL014469, 2002.

Owens, T. J., G. Zandt, and S. R. Taylor, Seismic evidence for an ancient rift beneath the Cumberland Plateau, Tennessee: a detailed analysis of broadband teleseismic $P$-waveforms, J. Geophys. Res., 89, 7783-7795, 1984.

Park, J. and V. Levin, Receiver functions from multiple-taper spectral correlation estimates, Bull. Seismol. Soc. Am., 90, 1507-1520, 2000.

Park, J., C. R. Lindberg, and F. L. Vernon III, Multitaper Spectral Analysis of High-Frequency Seismograms, J. Geophys. Res., 92, 12675-12684, 1987.

Sato, H., Y. Kojima, A. Murata, T. Ito, Y. Kaneda, M. Onishi, T. Iwasaki, Y. Oho, S. Ogino, K. Kano, T. Kawamura, E. Kurashimo, S. Koshiya, A. Takasu, T. Takeshita, N. Tsumura, Y. Terabayashi, F. Toyohara, T. Nakajima, K. Noda, Y. Hashimoto, S. Hasegawa, N. Hirata, T. Miyauchi, T. Miyata, S. Yamakita, T. Yoshida, S. Harder, K. Miller, G. Kaip, T. Ozawa, and T. Ikawa, Crustal Structre of the Outer Zone in Southwest Japan revealed by Shikoku and Seto-Inland-Sea Seismic Profiling in 2002, Bull. Earthq. Res. Inst., 80, 53-71, 2005 (in Japanese with English abstract).

Shibutani, T., The crust and slab structre beneath the eastern Shikoku by receiver function analyses, Earth Monthly, 23, 708-713, 2001 (in Japanese).

Shibutani, T., S. Nakao, R. Nishida, F. Takeuchi, K. Watanabe, and Y. Umeda, Swarm-like seismic activity in 1989, 1990 and 1997 preceding the 2000 Western Tottori Earthquake, Earth Planets Space, 54, 831845, 2002.

Shibutani, T., H. Katao, and Group for the dense aftershock observations of the 2000 Western Tottori Earthquake, Very dense aftershock observations of the 2000 Western Tottori Earthquake $\left(M_{\mathrm{j}}=7.3\right)$ in southwestern Honshu, Japan: high resolution aftershock distribution, focal mechanisms and 3-D velocity structure in the source region, Earth Planets Space, 57, 825-838, 2005.

Shiomi, K., H. Sato, K. Obara, and M. Ohtake, Configuration of subducting Philippine Sea plate beneath southwest Japan revealed from receiver function analysis based on the multivariate autoregressive model, $J$. Geophys. Res., 109, B04308, doi:10.1029/2003JB002774, 2004.

Soda, Y., T. Matsuzawa, and A. Hasegawa, Seismic velocity structure of the crust and uppermost mantle beneath the northeast Japan arc estimated from receiver functions, Zisin 2 (J. Seismol. Soc. Jpn.), 54, 347-363, 2001 (in Japanese with English abstract).

Tabei, T., M. Hashimoto, S. Miyazaki, K. Hirahara, F. Kimata, T. Matsushima, T. Tanaka, Y. Eguchi, T. Takaya, Y. Hoso, F. Ohya, and T. Kato, Subsurfacestructure and faulting of the Median Tectonic Line, southwest Japan inferred from GPS velocity field, Earth Planets Space, 54, 1065-1070, 2002.

Ueno, H., S. Hatakeyama, T. Aketagawa, J. Funasaki, and N. Hamada, Improvement of hypocenter determination procedures in the Japan Meteorological Agency, Q. J. Seismol., 65, 123-134, 2002 (in Japanese with English abstract).

Ueno, T., K. Ito, K. Yoshii, K. Matsumura, and H. Wada, Crustal Structure and Seismic Activity around the Atotsugawa Fault System, Central Honshu, Japan, Zisin 2 (J. Seismol. Soc. Jpn.), 58, 143-152, 2005 (in Japanese with English abstract).

Ueno, T., T. Shibutani, and K. Ito, Configuration of the continental Moho and Philippine Sea slab in Southwest Japan derived from receiver function analysis: Relation to subcrustal earthquakes, Bull. Seismol. Soc. Am., 2008 (accepted).

Wessel, P. and W. H. F. Smith Free software helps map and display data, Eos Trans. Am. Geophys. Union, 72, 441, 445-446, 1991.

Yamaguchi, S., Y. Kobayashi, N Oshiman, K. Tanimoto, H. Murakami, I. Shiozaki, M. Uyeshima, H. Utada, and N. Sumitomo, Preliminary report on regional resistivity variation inferred from the Network MT investigation in the Shikoku district, southwest Japan, Earth Planets Space, 51, 193-203, 1999.

Yamauchi, M., K. Hirahara, and T. Shibutani, High resolution receiver function imaging of the seismic velocity discontinuities in the crust and the uppermost mantle beneath southwest Japan, Earth Planets Space, 55, 59-64, 2003.

T. Ueno (e-mail: ueno@bosai.go.jp), T. Shibutani, and K. Ito 